DOI: 10.20472/BMC.2017.005.006

\title{
AMBROSE O. JAGONGO
}

Kenyatta University, Kenya

\section{STRATEGIC RESOURCE MOBILIZATION FOR ENTREPRENEURIAL FINANCING (A REVIEW OF IMPEDIMENTS FOR GROWTH OF WOMEN OWNED MSMES IN KENYA).}

\begin{abstract}
:
Strategic Resource Mobilization for Entrepreneurial Financing

(A review of impediments for growth of women owned MSMEs in Kenya).

Ambrose Jagongo, PhD, Kenyatta University - Kenya

Abstract

This study examined factors that affect resource mobilization for growth of women - owned MSMEs. It was based on the socio - economic cognitive entrepreneurial predisposition, aimed at discerning the complexities between the women entrepreneurship potentials and environmental constraints to resources for growth of the MSMEs. Resource mobilization is an apparent phenomenon in this study having been the bedrock to MSMEs financing in developing economies today. Many women - owned MSMEs have received financial and other assistance from various donors to start their business, but their inability to reduce reliance on external sources to grow had remained unexplained. The study hypothesized that the main constraints to resource mobilization for growth of women owned MSMEs arose from internal and external factors to the firm, the utilization of derived profits, and the characteristics of the woman entrepreneurs. The target population consisted of women entrepreneurs who had received assistance from the WEDCO project (3030), in Kisumu and Kakamega counties in Kenya. The sample size was determined through a multistage sampling process which culminated into 300. Questionnaires, interviews and observations were used to collect primary data. Data analysis was done by use of Pearson coefficient of correlation, chi-square tests of independence, analysis of variance. The major findings of the study were that the number of dependants; education level; cultural and religious attachments; endowed management skills; age and marital status had a significant relationship with the resource propensity amongst the women entrepreneurs. It was also revealed that environmental factors such as level of market competition; number and quality of employees, pricing of supplies; proximity to banking facilities; accessibility to information; economic inflation and physical infrastructures bore significant weight on the women's ability to save for the growth of their enterprises. The legal and regulatory framework significantly impeded resource ability for growth of women entrepreneurial ventures. It was concluded that the aforementioned factors should be addressed. Business development services should be enhanced and the women entrepreneurial competencies be improved to inculcate a culture of business resource for financing the operations and growth of women enterprises.
\end{abstract}

\section{Keywords:}

entrepreneurial ventures, entrepreneurship competencies, Constraints, entrepreneurship development, Women -Entrepreneurial-behavior, Resource mobilization, women enterprises, MSMEs. 
JEL Classification: D22, B54 


\subsection{Background to the Study}

Women have been initiating and starting their own businesses in unprecedented numbers in recent years. Some of them are leaving large corporations to "go it alone", for a number of career reasons: frustration at hitting the "glass ceiling", dissatisfaction with slow career advancements and unmet career expectations; corporate downsizing or to fulfill personal dreams of entrepreneurship of being autonomous and achieving success in business (Buttner and Holly 1998). Studies on SME development in Africa have cited the gender of an entrepreneur as an important factor in determining the enterprise's takeoff, growth and performance (Downing 1990; Parker, 1994, Aboagye, 1986). At the same time, women entrepreneurs have been identified as a significant and growing part of Kenyan business community (Dondo, 1998). Recent data on sole proprietorships and family holdings in Kenya provide evidence of the recent trends in women's share of the SME segment of Kenya's business sector (Analytical Report on gender dimensions Vol. $\mathrm{XI}$; Kenya Population and Housing census 1999). The report shows that women dominate the Kenyan population working on their own or family business holdings, where they form about $58 \%$ while less than $50 \%$ of the Kenyan male population work on family business holdings (GOK, 1989 \& GOK, 1999). The trend show that women entrepreneurship have grown substantially, however this growth is not engineered by mobilized resource, but rather from credit financing (Dondo, 1998).

In Kenya however, women entrepreneurs face unique socio-economic obstacles in running their businesses to an extent that their enterprises are likely to perform poorer compared to those run by their male counterparts (Musinga, 1994). Granted this, womenrun enterprises would tend to create fewer jobs and experience higher failure rate or retardation than men-run-ones due to management constraints. However, women owned enterprises employ more women than men, a trend positive to the Kenya's gender demographic statistics at present. This implies that women-owned enterprises posit greater opportunity to salvage the unemployment situation in Kenya towards poverty eradication, especially because women numbers and responsibilities are currently major subjects for attention if faster economic development is to be realized. As such, it is expected that women-owned enterprises should increase women employment more than men-owned enterprises (Musinga, 1994), hence the potential to create viable occupation for the ever increasing women population in Kenya (GOK, 999. Studies in entrepreneurship development have shown that a key way in reducing household poverty levels is to increase access of women to income-earning activities (employment) that is, to economically empower women (Musinga, 1994). This could be achieved through prudent resource mobilization for growth of women-owned enterprises, which would cause financial sustainability and business financial independence. 
The government recognition of the role and importance of the MSMEs in policy documents has gone through a number of stages as outlined in studies by King (1996), Gichira (1998) and McCormick (1988). The support of the Government of Kenya for this sector is evident in development plans and sessional papers, particularly Sessional Paper No. 1 (GoK 1986), Sessional paper No. 2 (GoK 1992) and Sessional paper no. 2 (GoK 1996a).

These documents acknowledge the increasing importance of the informal sector in economic development with respect to employment creation, particularly in the face of economic crisis and structural adjustment policies. They also show the government support to providing enabling policy environment by redressing licensing, tax, security of works and other regulatory restrictions on informal sector activities; stressed the role of private sector enterprises and initiatives, with the government playing mainly a facilitative role. The government also outlined the need for adequate access to credit, provision of management and technical training and other non-financial support programmes in business counseling, consulting, marketing and extension services. The cumulative effects of these strategies are to create an entrepreneurial culture in Kenya. Comparing MSMEs in Kenya with those in other African countries, it was established that the MSME sector in Kenya has more signs of dynamism and maturity than in most other African countries (GEMINI 1993). The adoption of financial liberalization policy alone has not been sufficient to generate a strong response in terms of increased resource mobilization and intermediation through the financial system; neither has it created wider access to financial services or increased investment by the private sector. Fragmentation of the financial markets has largely impeded efficient resource mobilization and restricted financial intermediation (Dondo, 1999).

Women Economic Development Corporation (WEDCO) is one of the various intermediary financial institutions in Kenya that receives support from the Department for International Development (DFID) to support small business start-up, in an attempt to alleviate poverty in Kenya. Intervention strategy of DFID for the MSME sector is being implemented by the British Assistance to Small Enterprise programme (BASE). The goal of BASE is to reduce the incidence of poverty in Kenya by assisting to generate additional off-farm employment, especially among poor people, and enhance incomes through increased productive capacity. (International Centre for Economic Growth 2000).

\subsection{Statement of the Problem.}

Sessional Paper No. 1 of 2005, on the Development of MSMEs for Wealth and Employment Creation for Poverty Reduction (GoK 2005), states that lack of access to credit is still a major constraint inhibiting the growth of the MSME sector. The issues and problems limiting the MSME acquisition of financial services relate to lack of tangible 
security and limited access to formal finance. The structured mechanisms that facilitate the flow of financial resources from the formal financial sector through the Micro Finance Institutions (MFIs) increases the cost of credit both to the entrepreneur and the financial institution. Mead (1989) argues that, resource mobilization is the second best alternative to credit financing because it is from resource that most investments in entrepreneurial ventures spring up. This indicates that prudent resource mobilization would offer longterm benefits to the entrepreneur and enhance enterprise development, yet resource mobilization does not thrive optimally in substance for entrepreneurship development.

According to Inziani, 2006, the question of who will successfully and adequately finance women MSMEs has remained unanswered for too long, he postulates that a larger MSME financing gap has been created that has affected their operations, performance and realization of their full potential. Michael Klain, 2007, argues that SME banking is considered a high-margin business with strong potential for profitability, cross-selling and risk diversification opportunities for the banking sector at the expense of the entrepreneurs. The same study portents that equity finance is more ideal for young, high growth and potentially high risk enterprises, typical of those owned by women entrepreneurs. That equity capital can be raised from internally generated funds, saved for business growth prospects. The gouging enquiry is therefore "what constraints the women entrepreneurs from mobilizing resource to grow their MSMEs?" Despite its importance, saving trends in Kenya have not been steady for the last two decades. Gross domestic resource (GDS) as a percentage of Gross Domestic Product (GDP) range between 3.6\% and 24.9\% with Growth Domestic Investment (GDI) being between 7.7\% and 25.0\%. In the last two decades, as shown in Appendix 5, GDS has been below GDI. This suggests in part that resources accumulated locally are inadequate for the country's investment needs. The external debt crisis of the 1990s coupled with the already widely acknowledged limitations of external donor financing (for example, tying of aids in various forms) emphasizes the need to increase domestic resource. Mayaka (2006) argues that women make good entrepreneurs because they are keen to plough back profits to boost their business, but most of them do not reach their business potential. Many women entrepreneurs, either individually or formed into business women groups receive financial and other assistance from various donors either as grants or loans to start or grow their enterprises, however, it has been observed that they continue to demand more assistance instead of mobilizing and re-investing the resource for their business growth and development ( McCormic \& Pedersen, 2001). It was against this background that this study sought to investigate constraints to resource mobilization for growth of women owned MSMEs which had received assistance for start - up. 


\subsection{General Objective}

The general objective of this study was to examine the factors that affect resource mobilization for growth of women - owned enterprises, especially those that were assisted to start-up. The specific objectives were:

i. To establish the relationship between internal factors (such as commitment to culture and religion, level of dependency, management skills, financial commitments and responsibilities, etc) and women - owned MSMEs resource mobilization for growth.

ii. To establish the relationship between women entrepreneurs characteristics and resource mobilization for growth of their MSMEs

iii. To establish the relationship between external factors, (such as government policy, infrastructure, security, financial support, information, economic factors, etc) and saving mobilization for growth of their enterprises.

The study hypotheses were:

1. There is no significant relationship between Internal/external factors and resource mobilization for growth of women - owned MSMEs

2. There is no significant relationship between characteristics of women entrepreneurs and resource mobilization for growth of women - owned MSMEs 
Figure 1: Conceptual Framework

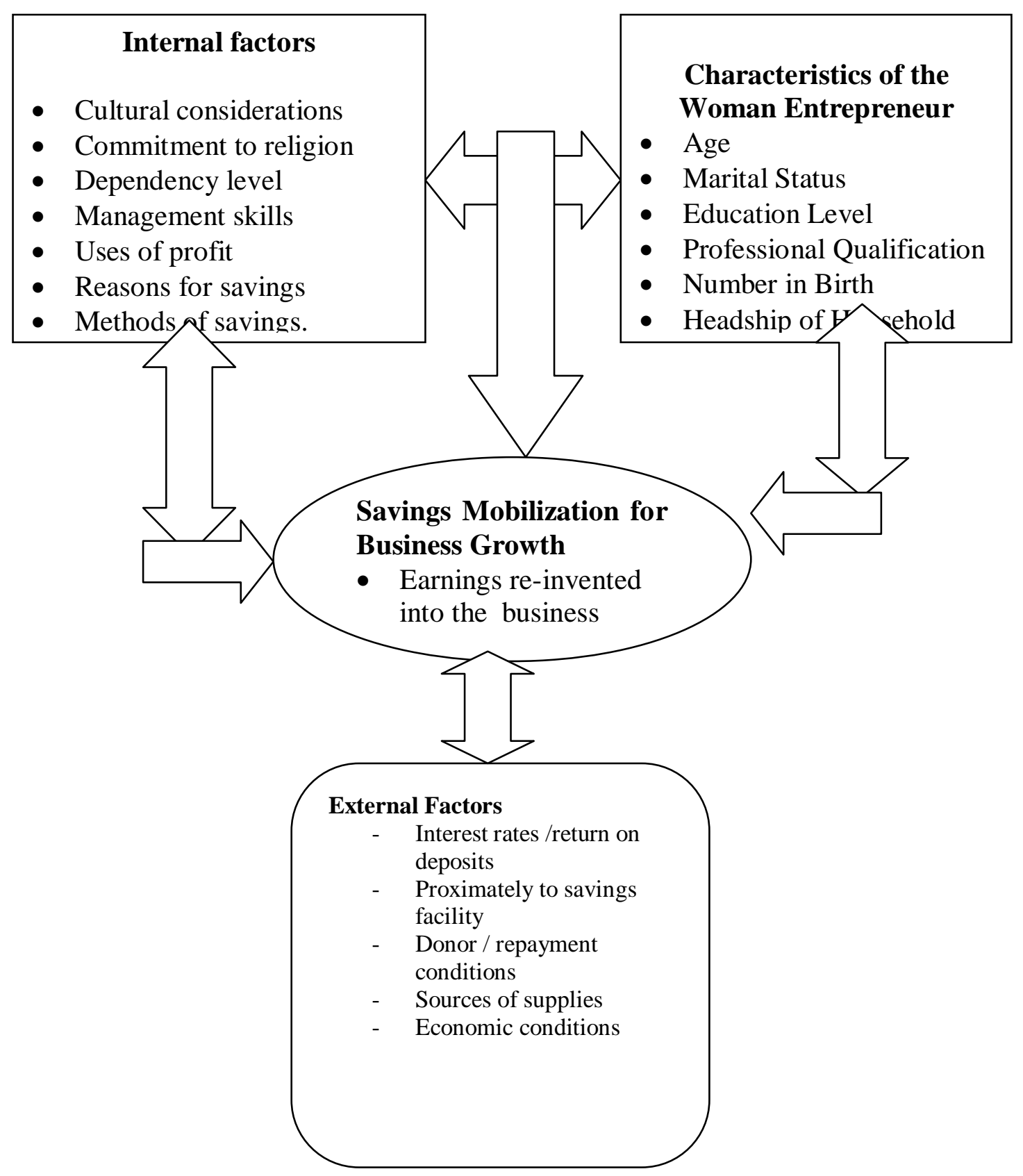




\subsection{The Research Design}

Descriptive survey of correlation design was employed in this study. The descriptive design was found to be suitable because it seeks to produce accurate profile of personal factors, events and situations, which were outlined in the conceptual framework of the study. The phenomenon is applicable to constraints to resource mobilization because the factors describe the women MSME operators' competencies and their business profiles. . Kilemi and Wamahiu (1995) postulate that descriptive survey produces data that is holistic, contextual, and rich in detail. However, in recognition of the fact that no single design exists in isolation, Saunders et al. (2003) postulate that combining different designs in one study enables triangulation and increases validity of the findings; for this reason, elements of exploratory design were applied. Correlational design was used to establish emerging causal relationship among the variables.

\subsection{Target Population}

The study population comprised 3,030 women in Kisumu and Kakamega districts in Western Kenya region who were operating MSMEs after being assisted by WEDCO at start-up stage, operating either commercial/ trading business, service oriented business, light manufacturing or a combination of these categories.

Table 1 Target population / sampling frame

\begin{tabular}{lllcc} 
Sampling Frames & Target & Total Sample & \multicolumn{2}{c}{ Sample Size } \\
& Population & size & Kisumu & Kakamega \\
Commercial women MSMEs & 1480 & $109(7.5 \%)$ & 64 & 53 \\
Service MSMEs & 1400 & $110(7.9 \%)$ & 63 & 62 \\
Light manufacturing MSMEs & 110 & $52(47.7 \%)$ & 26 & 14 \\
Combined commercial/ service & 40 & $29(69 \%)$ & 7 & 11 \\
& & & $\mathbf{1 6 0}$ & $\mathbf{1 4 0}$ \\
\hline Total & $\mathbf{3 , 0 3 0}$ & $\mathbf{3 0 0}$ &
\end{tabular}

Source: WEDCO (2006)

\subsection{Sampling}

Through Multi - stage Sampling, a sample of 300 was drawn from the 3030 WEDCO project women participants with the assistance of the countyproject managers, women group leaders and the local administration. The sample size determination, for this study was based on the formula in Saunders et al., (2003). The level of certainty of tolerance in any study is very important. This study, worked with $95 \%$ of certainty level. 


\subsubsection{Sample selection}

The sample selection commenced with the criteria for participation in the study, which is membership to WEDCO project. To participate, the women entrepreneur must have been assisted by WEDCO either to start or to grow the business. Secondly only those operated on own account and not being operated by the woman as an employee were considered for the study. The individual elements for this study were selected from the sampling frames using probability sampling. The use of different sampling methods was based on the different sampling frames in the study. Simple random sampling was used as the basic sampling design for selecting individual elements from a sampling frame. It consists of selecting a group of $\boldsymbol{n}$ sampling units in such a way that each sample of size $\boldsymbol{n}$ has the same chance of being selected.

\section{- Questionnaires}

Self-administered semi-structured questionnaires were used to produce the required data. The instrument was chosen because of its credit for flexibility in asking probing questions not beyond the focus of the study (Hoepfl 1997).

\section{- Interviews}

This was the data collection technique involving oral questioning of selected persons who were deemed to have information concerning the study. An in-depth interview was held with the WEDCO project managers and the women group leaders.

\section{- Focus group discussions}

The purpose of focus group discussions was to obtain in-depth information on concepts, perceptions and ideas of the women groups on as aspects of entrepreneurship generally and resource mobilization in particular. Participants were drawn from homogenous settings and a total of 10 and 9 women participants from the two districts participated in the discussion.

\section{- Observations}

This was a technique involving systematic selection, watching and recording behavior and characteristics of the women entrepreneurs at their business premises, and doing the same to stock levels and movement, visible assets, business records and the general establishment of the businesses. It was done through non-participant observations, i.e., the observer watched the situation and took note of the observed phenomena.

Observations in this survey served the following purposes:

- Offered additional, more accurate information on certain aspects of the study than the interviews and the questionnaires. 
- It equally acted as a check on information collected as well as supplementing verbal statements made by respondents. Observations equally assisted in validating and strengthening quality of the data gathered. Some of the observed aspects of entrepreneurship included; time management, resource allocations, workers supervision, storage, business set up, facilities and display, record keeping, treatment of customers, stocks, participation of the owners and visits by government / local authority agents.

\subsection{Data Analysis}

The coded data was subjected to descriptive statistical analysis, which included deriving frequency distribution, measures of central tendency (mean, and standard deviation) to test for normality; and the Chi-square test $\left(\chi^{2}\right)$ of independence was utilized to check the existing association between categorical data. Inferential statistical analysis, using the ANOVA and correlation analysis ware performed to examine the relationships between the internal factors and resource mobilization pattern of the women entrepreneurs and to establish the extent to which the derived profit was used for business growth and to determine the extent to which the government policy supports saving mobilization.

\section{FINDINGS, DISCUSSION AND INTERPRETATION}

\subsection{Response Rate}

The study yielded a response rate of $76.7 \%$. This high response rate was attributed to the excellent introduction done by WEDCO staff, the training and good service rendered by the research assistants and the use of structured questionnaire. It also reflected the high expectations, which the respondents harboured, that their challenges and problems could be solved through such entrepreneurship research.

\subsection{Profile of Women Entrepreneurs}

Internal factors were hypothesized as among the factors that affect resource amongst women owned or managed businesses. To analyze the internal factors, a profile of the women who participated in the study was generated. Information about their socialdemographic variables of age, ethnicity, religion, birth order, marital status, level of education, commitment to ethnic cultures, household membership dependency level, headship of the household, number of children and dependants in school and colleges, parents' business background, husband's business background (for those who were married), commitment of husbands and parents to religion and to ethnic cultures, and professional qualifications were produced. 
Table 2:1: Distribution of respondents based on bio-demographics/ Charateristics

\begin{tabular}{|l|l|r|r|}
\hline Variable & Category & $\begin{array}{c}\text { Frequency } \\
\mathbf{N = 2 3 0}\end{array}$ & Valid Percent \\
\hline Age of respondent & Below 16yrs & 2 & .9 \\
& 16 -32yrs & 68 & 30.1 \\
& 33 -55yrs & 140 & 61.9 \\
& Over 55yrs & 16 & 7.1 \\
\hline Number in birth & 1st born & 94 & 41.2 \\
& 2nd born & 52 & 22.8 \\
& 3rd born & 32 & 14.0 \\
& Last born & 34 & 14.9 \\
& Others & 16 & 7.0 \\
\hline Marital status & Single & 18 & 7.9 \\
& Married & 162 & 71.1 \\
& Divorced & 8 & 3.5 \\
& Widow & 40 & 17.5 \\
\hline Commitment to ethnic & Not committed & 54 & 23.9 \\
cultures and beliefs & Fairly committed & 128 & 56.6 \\
(by self) & Very committed & 36 & 15.9 \\
& Extremely & 8 & 3.5 \\
& committed & & \\
\hline
\end{tabular}

Source: Survey data (2006)

The results in table 2.1 are consistent with the findings of Hirsrich et. al., (2002), which showed that enterprise career progression, began between the ages 22 and 45 years, and that 30 years was the prime age to initiate enterprise start-up. The Pearson correlation coefficient between age and performance variables, had significant positive relationship, with number of full-time employees at the time of the study $(r=0.007, p<0.01$, profit first quarter $(r=0.016, p<0.05)$ profit second quarter $(r=0.003, p<0.05)$, profit third quarter $(r=0.038, p<0.05)$ and capital at the time of study $(r=0.007, p<0.01)$. These findings imply that as the age of the woman entrepreneur advanced, a resultant positive change in the performance and growth variables occurred. This could mean that with the advancement in age of the woman entrepreneur, the capacity to improve the business performance increased. The Pearson correlation coefficient between age and the resource mobilized $(r=0.003, p<0.05)$, also depicted a positive significant relationship which implies that as the age of the woman entrepreneur advanced, a resultant positive change in the perception about resource mobilization for growth of the enterprise occurred.

\section{- Number in Birth and Marital status}

As shown in Table 4.1, many of the respondents were either first born or second born.

First born comprised $41 \%(n=94)$, second born $22 \%(n=52)$, third born $14 \%(n=32)$ last born $14.9 \%(n=34)$ and where number of births were more than four comprised $7 \%$ 
$(n=16)$. With regard to marital status, Table 4.1 shows that the majority of the women studied were married $(n=162,71.1 \%)$ followed by widows $17.5 \%(n=40)$, those who were still single comprised $7.9 \%(n=18)$, divorced or separated accounted for $3.5 \%(n=8)$.

Table 2:2: Distribution of respondents based on level of commitment to ethnic cultures and beliefs

\begin{tabular}{|l|l|r|r|}
\hline Variable & Category & $\begin{array}{c}\text { Frequency } \\
\text { n=230 }\end{array}$ & Valid Percent \\
\hline Commitment to ethnic cultures and & & 54 & \\
beliefs (By self) & Not committed & 128 & 23.9 \\
& Fairly committed & 36 & 56.6 \\
& Very committed & 8 & 15.9 \\
& Extremely & 3.5 \\
& committed & 42 & \\
\hline Husbands commitment to ethnic & & 100 & 21.9 \\
cultures & Not committed & 42 & 52.1 \\
& Fairly committed & 8 & 21.9 \\
& Very committed & & 4.2 \\
& Extremely & 42 & \\
\hline Parents' commitment to ethnic & committed & 90 & 18.6 \\
cultures & Not committed & 76 & 39.8 \\
& Fairly committed & 18 & 33.6 \\
& Very committed & & 8.0 \\
\hline
\end{tabular}

Source: Survey data (2006)

As shown in Table 2.2, only $23.9 \%$ of the respondents indicated that they were not commitment to their ethnic cultures and beliefs. A majority $(74.8 \%)$ were found to be committed to various degrees to their ethnic cultures. Among those who were married, only $21.9 \%$ revealed that their husbands were not committed to cultural values. A total majority of $75.3 \%$ indicated that their husbands were committed to their ethnic cultures while $2.6 \%$ did not indicate. On the parents' commitment to ethnic cultures, $18.6 \%$ indicated that their parents were not committed. Majority, (79.9\%) said that their parents were committed while $1.7 \%$ did not indicate their parents' commitment to ethnic cultures. This implies that ethnic cultures were a very important factor that could not be ignored in women entrepreneurship development. Chi-square test of independence between tribe/ethnicity and rate of parents' commitment to ethnic cultures show a significant relation at 0.05 level between the variables $\left(\chi^{2}=25.084 p=0.003\right)$.

\section{- Level of Education and Professional Qualification}

The results indicated that majority of the respondents had attained secondary levels ( $55.4 \%$ ), With regard to professional skills, $76.5 \%$ possessed no professional qualification. For the women entrepreneurs in the sample, who were married, the majority of their husbands had secondary level of education $63.1 \%$ and no higher professional skills 
40.4\%. This study compared very well with the national baseline survey (1999) which noted that participants in the formal sector with primary level of education were $54 \%$, while those with secondary level were $33 \%$. These results of this study however show that the women entrepreneurs' without any formal education had reduced while those with secondary level had increased as compared with the national baseline survey (1999). The picture was confirmed by a nonparametric correlation (Table 2.3) which showed Spearman's $(\boldsymbol{r}=\mathbf{- 0 . 1 8 4})$ indicating that there was very high significant correlation at 0.01 level between highest level of education of the women in entrepreneurs and level of commitment to ethnic cultures and beliefs. This implies that the higher the levels of education attained, the less committed the individuals to ethnic cultures and beliefs.

Table 2.3: Nonparametric correlations between level of education and commitment to ethnic cultures \& beliefs

\begin{tabular}{|c|c|c|c|c|}
\hline & & & $\begin{array}{l}\text { Highest level of } \\
\text { education by self }\end{array}$ & $\begin{array}{l}\text { How committed to ethnic } \\
\text { cultures and beliefs }\end{array}$ \\
\hline \multirow[t]{4}{*}{$\begin{array}{l}\text { Spearman's } \\
\text { rho }\end{array}$} & $\begin{array}{l}\text { Highest } \\
\text { level of } \\
\text { education } \\
\text { by self }\end{array}$ & $\begin{array}{l}\text { Correlation } \\
\text { Coefficient }\end{array}$ & 1.000 & $-.184\left(^{* *}\right)$ \\
\hline & & $\mathrm{N}$ & 224 & 222 \\
\hline & $\begin{array}{l}\text { How } \\
\text { committed } \\
\text { to ethnic } \\
\text { cultures } \\
\text { and beliefs }\end{array}$ & $\begin{array}{l}\text { Correlation } \\
\text { Coefficient }\end{array}$ & $-.184\left(^{* \star}\right)$ & 1.000 \\
\hline & & $\mathrm{N}$ & 222 & 226 \\
\hline
\end{tabular}

Source: Survey data (2006)

${ }^{* *}$ Correlation is significant at the 0.01 level (2-tailed).

The relationship between the woman entrepreneurs' education level and the resource mobilization was analyzed by Pearson's correlation coefficient. The results show that there was no statistical significant relationship $(p>0.05)$. This implies that woman entrepreneurs' education level may not have much impact on resource mobilization.

\section{- Household Headship}

Of the total respondents, $64.5 \%(n=142)$ indicated that their husbands headed their households. A paltry $35 \%(n=78)$ said they were the heads of their households. This implies that the majority of the women entrepreneurs were controlled by their husbands, a situation that could influence the uses of business generated funds in general and resource mobilization in particular and delay entrepreneurial decision-making for instance, on business growth prospects. This supports the Poverty Reduction Strategy for 2000-2003 which reports that since female-headed households constitute significant proportions of the poor, any intervention must be gender sensitive, to enable women 
entrepreneurs to make a significant contribution to economic development and industrialization (GoK, 1986). The findings are also in agreement with Hornaday and Aboud (1971) who reveal that support, independence and leadership in households, women groups or other forums are other personality traits that make women to be successful entrepreneurs.

\section{- Household Size and Level of Dependants}

The respondents were asked to state the total number of their household members. Of the total respondents, 53\% $(n=116)$ indicated 2-6 members, 28.4\% $(n=62)$ indicated $7-10$ members, $7.3 \% \quad(n=12)$ said their households comprised theMSMElves and their husbands; another $5.2 \%(n=12)$ provided that their household members were well above 10. The respondents were also requested to state the number of dependants they take care of and the results were: $56 \%$ take care of 1-5 dependants, $20.0 \%$ take care of $6-10$ dependants, $19.2 \%$ take care of no dependant at all while $5.5 \%$ had more than 10 dependants. A cross tabulation of highest level of education and number of own children revealed that all (100\%) of respondents with no formal education had 6-10 children, $66.7 \%$ of those with primary level had $1-5,87.7 \%$ of those with secondary had $1-5$ while $60 \%$ of those with higher than secondary had 1-5 children. The relationship between the level of education and the number of own children was such that those with no formal education had significantly high number of children, $\left(\chi^{2}=27.817\right.$, $\left.\mathrm{df}=6, \mathrm{p}<0.5\right)$.

\section{- Commitment to Religion Activities}

95.5\% were committed to their religion personally, $91.6 \%$ had husbands who were committed while $95.0 \%$ had parents who were committed to religion.

\section{Involvement and Participation in Religious Activities}

\begin{tabular}{|l|l|r|}
\hline Variable & Category & Valid Percent \\
\hline Being a religious leader & Not important & 59.0 \\
& Slightly important & 21.9 \\
& Very important & 17.1 \\
& Extremely important & 1.9 \\
\hline Attending all religious services & & Not important \\
& Slightly important & 21.7 \\
& Very important & 21.7 \\
& Extremely important & 40.6 \\
\hline Attending only crucial religious & Not important & 16.0 \\
\hline activities & Slightly important & 33.0 \\
& Very important & 19.4 \\
& Extremely important & 38.8 \\
& & 8.7 \\
\hline
\end{tabular}




\begin{tabular}{|l|l|r|}
\hline Giving donations & Not important & 9.2 \\
& Slightly important & 22.9 \\
& Very important & 52.3 \\
& Extremely important & 15.6 \\
\hline Giving tithe as required & Not important & 16.3 \\
& Slightly important & 20.2 \\
& Very important & 41.3 \\
& Extremely important & 22.1 \\
\hline
\end{tabular}

\section{- Being a Religious Leader}

The respondents were asked how they viewed or rate importance of their involvement and participation in religious activities. 59\% $(n=124)$ said being religious leader was not important to them, $21.9 \%(n=46)$ found religious leadership very important while only $1.9 \%(n=4)$ considered it extremely important.

\section{- Attending all religious activities}

Attending all religious services was stated to be crucial by $78.3 \%$, out of whom $40.6 \%$ said it is very important to them, $21.7 \%$ found it slightly important and $16 \%$ found it extremely important. On the other hand, $21.7 \%$ said it was not important to attend all religious services.

\section{- Attending only Crucial Religious Activities}

Majority (67\%) of the respondents said that participating in crucial religious activities was important, while $33 \%$ indicated that it was necessary for them to attend over crucial religious activities only.

\section{- Giving of Tithe as Required}

The majority $83.7 \%$ of the respondents consider giving of the tithe as required necessary. Out of this, $41.3 \%$ said it was very important, $22.1 \%$ found it extremely necessary and $20.2 \%$ ranked giving of the required tithe as slightly important. This implies that a reasonable percentage of the earnings of women entrepreneurs were set aside for tithe.

McClellan and Hagen (1962) that Psychological and social factors such as personality influence entrepreneurship. It implies that entrepreneurship behavior among the women may result from attitudes, which in turn are affected by social environment including parental attachment, weight of husband's opinion, involvement in religious activities and cultural attachments.) 


\section{- Household Membership and Level of Dependency}

The results indicate that $53.2 \%(n=116)$ had between 2 and 6 members in their households, 28.4\% ( $n=62)$ had between 7-10 members, 12.8\% ( $n=28)$ comprised households with the women only or the woman and her husband only.

\section{- Number of Dependants other than Own Children}

$56.6 \%$ of the respondents indicated that they had between 1and 5 dependants, 20.2\% had $6-10$ dependants, $19.2 \%$ had no dependants, while $4 \%$ had over 10 dependants to take care of.

\section{Table 2.4: Correlation between profits and future business plans}

\begin{tabular}{|c|c|c|c|c|c|c|c|c|c|}
\hline \multirow[t]{2}{*}{$\begin{array}{l}\text { Profits from } \\
\text { business } \\
\text { independen } \\
t \text { variable) }\end{array}$} & & \multicolumn{8}{|c|}{$\begin{array}{c}\text { Future business plans } \\
\text { (Dependent variable) } \\
\qquad n=230\end{array}$} \\
\hline & & $\begin{array}{c}\text { Seek } \\
\text { more } \\
\text { credit for } \\
\text { expansio } \\
n\end{array}$ & $\begin{array}{l}\text { Use } \\
\text { resource } \\
\text { for } \\
\text { expansion }\end{array}$ & $\begin{array}{l}\text { Add } \\
\text { more } \\
\text { employe } \\
\text { es }\end{array}$ & $\begin{array}{l}\text { Split } \\
\text { current } \\
\text { business } \\
\text { to other } \\
\text { locations }\end{array}$ & $\begin{array}{l}\text { Close } \\
\text { the } \\
\text { busine } \\
\text { ss }\end{array}$ & $\begin{array}{c}\text { Get into } \\
\text { partnership }\end{array}$ & $\begin{array}{l}\text { Expand } \\
\text { the } \\
\text { market }\end{array}$ & $\begin{array}{l}\text { Increas } \\
\text { e } \\
\text { resourc } \\
\text { e }\end{array}$ \\
\hline $\begin{array}{l}1^{\text {st }} \text { quarter } \\
2^{\text {nd }} \text { quarter } \\
3^{\text {rd }} \text { quarter } \\
4^{\text {th }} \text { quarter }\end{array}$ & $\begin{array}{l}r . \\
p \\
r . \\
p \\
r . \\
p \\
r . \\
p\end{array}$ & $\begin{array}{l}.021 \\
.839 \\
.147 \\
.188 \\
.143 \\
.206 \\
.005 \\
.968 \\
\end{array}$ & $\begin{array}{c}-.012 \\
.867 \\
-.025 \\
.748 \\
-.034 \\
.663 \\
-.083 \\
.292\end{array}$ & $\begin{array}{l}.236\left(^{(*}\right) \\
.004 \\
.208\left(^{*}\right) \\
.018 \\
\left..227^{* *}\right) \\
\left..009^{(* \star}\right) \\
\left..243^{(*}\right) \\
.006\end{array}$ & $\begin{array}{l}.129 \\
.106 \\
.155 \\
.066 \\
.106 \\
.251 \\
.017 \\
.839\end{array}$ & $\begin{array}{c}-.053 \\
.537 \\
-.049 \\
.588 \\
-.017 \\
.849 \\
-.116 \\
.203\end{array}$ & $\begin{array}{r}-.021 \\
.796 \\
-.025 \\
.779 \\
-.157 \\
.074 \\
-.096 \\
.279 \\
\end{array}$ & $\begin{array}{r}-.028 \\
.708 \\
-.014 \\
.863 \\
-.009 \\
.908 \\
-.116 \\
.159 \\
\end{array}$ & $\begin{array}{l}-.088 \\
.240 \\
-.060 \\
.445 \\
-.023 \\
.778 \\
-.020 \\
.810 \\
\end{array}$ \\
\hline
\end{tabular}

(*) Significant at 0.05level

$\left.{ }^{* *}\right)$ Significant at 0.01 level

Source: Survey data (2006)

\section{Correlation between Profit and Major Items of Expenditure}

Correlation analyses between profits from the business and major items of expenditure show both positive and negative associations. Very high significant positive correlation at 0.01 levels was found between distribution of disposable income on school fees and profits for all the quarters of the year. Significant positive association at 0.05 level was revealed between expenditures on rent, salaries and wages and the whole year's profits. There was insignificant relationship between loan repayments and the year's profits. However interestingly, there was a significant negative correlation at 0.05 level between 
resource and the quarters' profits, while only a negative picture of association was revealed between expenditure on personal effects and the profits.

Table 2.5: Correlation between profits from the business and major items of expenditure

\begin{tabular}{|c|c|c|c|c|c|c|}
\hline $\begin{array}{l}\text { Profits from } \\
\text { business } \\
\text { independent } \\
\text { variable) }\end{array}$ & \multirow[b]{2}{*}{$\begin{array}{l}r . \\
p \\
r . \\
p \\
r . \\
p \\
r . \\
p\end{array}$} & \multicolumn{5}{|c|}{$\begin{array}{l}\text { Distribution of disposable income on major items of expenditure } \\
\qquad \begin{array}{c}\text { (Dependent variable) } \\
n=230\end{array}\end{array}$} \\
\hline $\begin{array}{l}\text { First quarter } \\
\text { Second quarter } \\
\text { Third quarter } \\
\text { Fourth quarter }\end{array}$ & & $\begin{array}{l}\text { Rent, salaries } \\
\text { and wages } \\
.136\left(^{*}\right) \\
.008 \\
.137\left(^{*}\right) \\
.009 \\
.173\left(^{*}\right) \\
.040 \\
.093\left(^{*}\right) \\
.007\end{array}$ & $\begin{array}{l}\begin{array}{l}\text { Personal } \\
\text { effects }\end{array} \\
-.130 \\
.686 \\
-.046 \\
.572 \\
-.029 \\
.716 \\
-.069 \\
.399\end{array}$ & $\begin{array}{l}\text { School fees } \\
\left..201^{(*}\right) \\
\left..017^{(*}\right) \\
.04\left(^{*}\right) \\
\left..016^{(\star \star}\right) \\
.049^{(1 *} \\
.1955^{(0)}\end{array}$ & $\begin{array}{l}\text { Loan } \\
\text { repayment } \\
.062 \\
.406 \\
.120 \\
.137 \\
.129 \\
.111 \\
.195 \\
.017\end{array}$ & $\begin{array}{l}\text { Resourc } \\
\mathrm{e} \\
-.166\left(^{*}\right) \\
.007 \\
-.028\left(^{*}\right) \\
.007 \\
-.030\left(^{*}\right) \\
.009 \\
-.062\left(^{*}\right) \\
.010 \\
\end{array}$ \\
\hline
\end{tabular}

(*) Significant at 0.05level

$\left({ }^{*}\right)$ Significant at 0.01 level

Source: Survey data (2006)

\section{Chi-square Tests and Correlations between External Factors and Resource}

Several external factors were tested against the resource, to determine interdependence and effect for growth prospects. The findings revealed as follows:

\section{- Accessibility to Credit and Resource Mobilization}

To establish the relationship between resource mobilization and external factors, chi square tests and correlation analysis were conducted. The results revealed that $8.5 \%$ of those who did not access credit easily saved nothing; $46.2 \%$ of this category saved between up to $25 \%$ of their income while $54.8 \%$ saved between 26 to $50 \%$. Accessibility to credit has direct and proportionate negative impact on resource mobilization. As shown in Table 4.21, there is a very significant association with a negative relationship between accessibility to credit and resource mobilization, with those who accessed credit easily saving less $\left(\chi^{2}=2755\right.$ and $\left.r=-0.248\right)$. This implies that as accessibility to credit increased, the propensity to saving reduced, among women entrepreneurs. Those who were able to access more credit easily saved very little.

\section{- Competition and Resource Mobilization}

Findings indicated that $35.1 \%$ of those who experienced stiff completion saved nothing, $28.8 \%$ of this category saved between 1 to $25 \%, 16.1 \%$ saved between 26 to $50 \%, 15 \%$ saved between 51 to $75 \%$ while $5 \%$ saved between $75 \%$. There is a significant negative 
relationship between market competition and resource mobilization, with those who experienced less completion saving more $\left(\chi^{2}=34.081\right.$ and $\left.\mathbf{r}=-0.142\right)$, as shown in Table 4.22 This implies that businesses that experienced more advanced completion for their products saved less.

- Inflation Rate and Resource Mobilization

The findings revealed that $86.65 \%$ of the respondents, who indicated that they were affected by economic inflation rate, saved nothing from their income. Another $33.35 \%$ of this category saved between 1 to $25 \%, 23.35 \%$ saved between 26 to $50 \%$ while only $3.8 \%$ saved over $50 \%$. There is a significant negative association between economic inflation rate and resource mobilization, with those who indicated they are affected more, saving less $\left(\chi^{2}=26.68\right.$ and $\left.r=-0.191\right)$, as shown in Table 4.22.

\section{- Prevailing Political Situation and Resource Mobilization}

There was very high significant relationship between changes on prevailing political situations and resource mobilization at $\left(\chi^{2}=16.454\right.$ and $\left.r=0.232\right)$ as shown in Table 4.22. This implies that changes in political situations affected the resource behaviour of the women entrepreneurs.

Table 2.5: Correlation analysis between external factors and resource mobilization.

\begin{tabular}{|c|}
\hline $\begin{array}{l}\text { External factors } \\
\text { Independent variables }\end{array}$ \\
\hline Accessibility to credit \\
\hline Completion \\
\hline Economic inflation rate \\
\hline Access to market for produce \\
\hline Political situation \\
\hline Government / L.A agents \\
\hline
\end{tabular}

(*) Significant at 0.05level

${ }^{* *}$ Significant at 0.001 level

Source: Survey data (2006)

The correlation analyses between external factors and resource mobilization are largely negative as presented in Table 22. Accessibility to credit though negatively related to 
resource is found to be very significant at $(r=-0.248, p=0.001)$. Economic inflation rate and effect of government agents are also negatively related to resource but are significant at $(r=-0.191, p=0.011$ and $-0.167, p=0.023$ respectively.) while nature of completion is negatively related to resource and moderately significant at $(r=-0.142$, $p=0.055$ ). There is a very high correlation between the prevailing political situation and resource $(r=0.232, p=0.002)$. There is however no significant relationship between access to market for produce and resource. This shows that the external factors largely portrayed negative implications to the progression of entrepreneurial activities in general and to resource for growth among women entrepreneurs in particular.

\section{- Books of Accounts and Profit Determination}

Of all those who responded, only $8.3 \%$ indicated that they always kept proper books of accounts, $20 \%$ said they apply this skill sometimes, $10.2 \%$ said they hardly kept books of accounts while $61.1 \%$ indicated they that they never kept proper records of accounts. Similarly, $76 \%$ of the respondents said that they did not calculate profits properly; $8.6 \%$ said that they sometimes derived their profits accurately while only $1.9 \%$ indicated that they used proper methods always.

\section{- Interest Rates on Resource}

To determine the effect of interest rates on resource among women entrepreneurs, the respondents were required to indicate the interest rate in their resource facilities and to state whether the rate affected their decisions on resource. The results provided that there was no significant relationship between interest rates and the decision to save $\left(\chi^{2}=\right.$ $60.533, \mathrm{df}=22 \mathrm{P}=00$ ). The relationship between resource to earn interest and the profits for all four quarters of the year was found to be insignificant. (First quarter: $\chi^{2}=29.592$, $\mathrm{df}=9 \mathrm{P}=001$, second quarter: $\chi^{2}=16.827, \mathrm{df}=9 \mathrm{P}=001$, third quarter: $\chi^{2}=32.406, \mathrm{df}=12$ $\mathrm{P}=001$ fourth quarter: $\chi^{2}=28.197, \mathrm{df}=12 \mathrm{P}=005$ ).

\subsection{Conclusions}

This study dealt with socio-demographic factors, economic, household and personal characteristics, and the relationship between these internal factors with the resource mobilization among the women entrepreneurs. The study showed varied findings, on the variable relationships. Ethnicity, level of education and professional qualifications (by self or husband); marital status, age and birth order were consistent with the existing literature. However, commitments to religion and to culture (by self or husband or parents), level of dependants, childhood orientation and family business background had been scantly covered in the literature hence this study provided exploratory findings. 
Women entrepreneurs were found to suffer three most common but irresistible situations:

- they govern large/ extended households and

- are committed to religious activities and

- are committed ethnic cultures.

In addition, those who were married have to submit to their husbands command in cultural and religious beliefs. Further, the findings of this study show that a number of social-cultural factors influence women entrepreneurship as a whole and business dynamics resulting in their growth or decline thus the birth, expansion, contraction, and death of women-owned SMEs are grossly affected by internal factors of firm revolving around the women entrepreneurs competencies. The main factors that contributed to the women-owned enterprises start-up were found to be; first lack of employment, lack of capital and lack of support and information.

This conclusion is supported by the results in chapter four. Other motivating factors for women owned enterprises start-up, revealed during focus group discussions and interview, were: trying out a skill first, the best alternative to earning a living, need to control own life and personal fulfillment in that order. Most of the women respondents were self motivated at start-up stages of their enterprise but were overwhelmed to grow or graduate their businesses owing to the large domestic chores and responsibilities arising from both economical and socio-cultural burdens and challenges.

Most of the women entrepreneurs never received any training, relied on their resource for additional sources of capital, and experienced low levels of satisfaction. Frustration and need to control own life was also indicated as reasons for mobilizing resource. The study recommends for:

(i) Strategies to enhance resource mobilization be put in place and institutions must recognize the uniqueness of the women competencies so as to offer relevant encouragement and support.

(ii) Institutional arrangements in the informal credit market such as Cooperative Societies, the Rotating Resource and Credit Associations (ROSCAS) be encouraged for the women entrepreneurs. These would continue to serve as a vehicle for pooling small resource.

(iii) Family household sizes and dependency levels must be addressed in order to put the women entrepreneurs in the category of active savers. The regulatory agencies in general and the government in particular should move in with goodwill to assist in this issue. For family household reduction initiatives to succeed, the 
beneficiaries must be empowered and made to contribute to the wealth of the economy through their involvement in viable businesses or trade.

(iv) Sensitization and awareness programmes should be enhanced to expose the women entrepreneurs to conducive financial environment that engenders greater competition. This will facilitate the introduction of new resource products for women in business that could enhance the mobilization of resources for development.

(v) Voluntary resource, involuntary resource and policy induced resource should be encouraged to generate increased output to deal with the situation of less than full employment which currently exists among women entrepreneurs. With the same breath, the importance of resource in Kenya as a developing economy should be addressed through attempts to bridging the resource gap to enhance resource culture amongst the women entrepreneurs.

(vi) Resource can be harnessed from the women through innovative products that meet their needs. At the same time, there should be extensive network of bank branches in the country, without a biased concentration in the urban centers, since proximity to banking facility was raised as an important factor for saving. This can be achieved through enhanced financial intermediation.

\section{References}

Adaya, S. 2000. Exploring Entrepreneurship in a Declining Economy. Journal of Developmental Entrepreneurship, 5(1), 41-47.

Alila, P.O. 1988. Rural Development in Kenya: A Review of Past Experiences. Regional Development Dialogue. Vol. No.2. Summer.

Changati, R. 1986. Management in Women- owned Enterprises. Journal of Small Business Management 24(4)

Cooper, D. R., and P. S. Schilder, 2001. Business Research Methods ( $7^{\text {th }}$ ed). Boston: McGraw-Hill.

Donald Kisilu Kombo and Delno L. A. Tromp 2006. Proposal and Thesis Writing.

Dondo A. 1994. Credit to the Informal Sector. Approaches and models experienced.

Dondo A. and G. Ongile. 1994. Small and Micro-enterprise Assistance.

Gay, L. R., 1981. Educational Research Competencies for Analysis and Application. London: Charies E. Mervil Publishing company A. Bell and Howell company.

Gichira, R. 1998. An Analysis of the Laws and Regulations affecting the Development of the Informal Sector in Kenya . K-REP. Research. Paper No. 5: K-REP 
Government of Kenya, 1986. Sessional Paper No.1 of 1986 Economic Management for Renewed Growth. Nairobi: Government Printers.

1992. Sessional Paper No.2 of 1992 on Small Enterprise and Jua Kali Development. Nairobi: Government Printer. 1999. Economic Survey 1999. Nairobi: Central Bureau of Statistics (CBS).

2003. Economic Recovery Strategy for Wealth and Employment Creation, 2003-2007. Nairobi: Government Printer.

2005. Sessional Paper No.2 of 2005. Development of Micro and Small Enterprises for Wealth and Employment Creation for Poverty Reduction. Government Printers Nairobi.

Ikiara, G. 1995. The Role of Government Institutions in Creating Competitive Industry in Kenya. Report of The National Seminar on Industry Transformation of Kenya to be Newly Industrialized by The Year 2010. Held At Safari Park Hotel On $15^{\text {th }}$ February 1995.

International Labor Organization 1972. Employment, Incomes and Equality: A Strategy for Increasing Productive Employment in Kenya: Geneva: ILO.

, 1999. Micro and Small Enterprise Development and Poverty Alleviation in Thailand: Project ILO/UNDP: THA/99/03 Working Paper 2. Geneva.

Kagira, B. M. 1989. Private Resource in Kenya: An Empirical Study, University of Nairobi, 1989.

Karega, R. M., 1996. Women's Groups: From Welfare to Small-scale Businesses in Kenya. Small Enterprises Development Journal Volume 7 No. 1.

King, K. 1996. Jobless in Kenya. Kenyatta University Bureau of Education Research, 4p.

Kibas, P., and G. O. K'aol, 2004. The Kenya Entrepreneur: Typologies and Characteristics. International Council for Small Business $49^{\text {th }}$ Conference Proceeding, 20-23 June 2004, Johannesburg.

Kilemi, M. and Wamahiu, S. P., 1995. Issues in Educational Research in Africa: EastAfrican Educational Publishers, Nairobi.

K'Obonyo, P., G. K. Ikiara, W. Medulla, C.Abuotha, G. Ongile, and D. McCormick, 1999. Complying with Business Regulation in Kenya. Occasional Paper No. 64, Institute of Development Studies, University of Nairobi.

Kothari, C .R. 2003, Research Methodology: Methods and Techniques. Second Edition. New Age International $(P)$ Ltd.

McCormick, D. 1988. Funds and Formality. Very Small Manufacturers in Nairobi. In Political Economy of Kenya, edited by Schartzerberg, M. G. New York: Praeger Publishers.

Mead, R. 1989. International Management: Cross Cultural Dimensions. Malden, Massachusetts, USA: Blackwell Publishers Inc. 
Mugenda, O. M., and A. G. Mugenda 1999. Research Methods: Quantitative and Qualitative Approaches. Nairobi: Acts Press.

Musinga, J. M. 2000 The Impact of Small Loans on Employment in Small and Micro-Enterprises in Kenya. K-Rep Research paper No.19, Nairobi Kenya.

Namusonge, G. S. 1998. Determinants of Growth Oriented Small and Medium Enterprises in Nairobi Kenya. Unpublished Ph.D thesis, Jomo Kenyatta University of Agriculture and Technology.

Ngugi, W, E. 1991. Saving Behaviour of Rural Households in Kenya: A Comparative Study of Siaya and Nyandarua Districts, University of Nairobi, 1991.

Oketch, H. 1999. Credit and Finance. In: Mullei, A. and Bokea, C. (Eds), Micro and Small Enterprises in Kenya: Agenda for Improving the Policy Environment Nairobi: ICEG, Nairobi.

Otero, M.1989. A Handful of Rice: Resource Mobilization by Micro Enterprise Programmes Perspectives for the Future; Accessional Monograph Series No.3.

Rhyne, E. 1992. A New View of Finance Programme Evaluation GEMMINI Working Paper No. 32.

Robinson, S. M.,1992. Financial Intermediation at the Local level: Lessons from Indonesia part 1. The Bank Rakyat Indonesia, Rural Banking, 1970-1991, Harvard Institute for International Development, Discussion Paper No. 434, , 1994. Saving Mobilization and Micro Enterprise Finance: The Indonesia experience. In (Eds), Otero, M and E. Rhyne; The new World of Micro enterprise finance: Building Healthy Financial Institutions for the Poor, Kumarian press, Inc., Connecticut.

,1994. Financial Intermediation at the Local Level: Lessons from Indonesia Part 2. A Theoretical Perspective, Harvard Institute for International Development, Discussion Paper No. 482, March.

Saunders, M., P. Lewis, and Thornhill, A. 2003. Research Methods for Business Students ( $3^{\text {rd }}$ Ed). Harlow: Prentice Hall.

Schumpeter, J. A. 1961. The Theory of Economic Development. New York: Oxford University Press. 
MINISTRY OF EDUCATION, SCIENCE \& TECHNOLOGY

Telegrams: EDUCATION", Nairobi

Fax No.

Telephone: 318581

When replying please quote

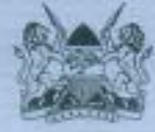

sanaur of crey,
JOGOO HOUSE HARAMBEE AVENUE

P. O. Box 30040

NAIROBI

KENYA

MOEST $13 / 001 / 35 C 598 / 2$

\section{$2^{\text {th }}$ December, 2005}

\section{JagongoAmbrose Ouma \\ Kenyatta University \\ P.O. BOX 43844 \\ NAIROB!}

Dear Sir

\section{RE: RESEARCH AUTHORIZATION}

Following your application for authority to carry out research on "Factors affecting savings motilizaliun for growth of Women owned micro and small enterprises in Western Kenya".

1 am pleased to inform you that you have been authorized to carry out research in Kakamega, Kisumu, Siaya and Rachuonyo District for a period ending $30^{\text {th }}$ December. 2006.

You are advised to report to the District Commissioners and the District Education Ufficers of the respective Districts you will visit before embarking on your research project.

Uipon completion of your research you are expected to submit two copies of your research report to this Office.

Yours faitinfully

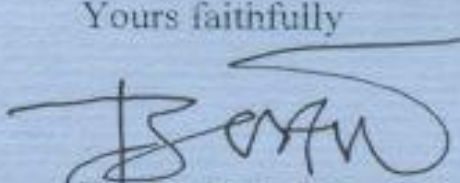

B. O. ADEWA

FOR: PERMANENT SECRETARY 